\title{
Türkiye'de Mimarlık ve İç Mimarlık Öğretiminde Yangın Güvenliğine Samsun Özelinden Bakış
}

\begin{abstract}
Alper BODUR ${ }^{1}$
Öz

Yangın, binalara zarar vermesi ve insanlara olumsuz psikolojik etkisi nedeniyle ele alınması gereken en önemli tehlikelerden biridir. Mimari bir yapının yangına karşı sağlamlığı ve dirençliliği, teknik bir konu olduğu kadar bir eğitim sorunudur. Bu bağlamda, mimarların ve iç mimarların yangın güvenliği ile ilgili eğitim seviyelerinin yüksek tutulması, bir mimari yapının yangına karşı dayanıklılığını artıran bir faktördür. Her ne kadar tüm mimar ve iç mimarların uzmanlık seviyesinde yangın bilgisine sahip olması istenmemekle birlikte, ilgili yönetmelikleri ve yapılması gerekenleri asgari derecede bilmesi ve tasarımda bu bilgileri kullanabilmesi beklenmektedir. Bununla beraber, mimar ve iç mimarların yangınla ilgili eğitim süreçlerinin, meslek öğretimi sırasında doğrudan ve etkin bir biçimde verilmesi oldukça önemlidir. Bu çalışmada, Türkiye'ye bağlı üniversitelerde mimarlık, iç mimarlık ile iç mimarlık ve çevre tasarımı bölümlerinde yangın güvenliği ile ilgili doğrudan verilen temel eğitim ve bilgiler Ondokuz Mayıs Üniversitesi Mimarlık Fakültesi'nde yapılan anket çalışması ile birlikte analiz edilmektedir. Ayrıca, konu ile ilgili yapılması gerekenler etraflıca değerlendirilmekte ve karar vericilere yönelik öneriler getirilmektedir. Konuyla ilgili kaynakların azlığından dolayı bu çalışma, ulaştığı sonuçlar ve getirdiği öneriler bakımından yapılacak araştırmalara ışık tutacak bilgileri içermektedir. Çalışma sonucunda, Türkiye'de mimarlık, iç mimarlık ile iç mimarlık ve çevre tasarımı bölümlerinde verilen yangın güvenliği eğitimlerinin halen yeterince yaygınlaşmadığı ve bu konuda eksiklikler olduğu sonucuna ulaşılmıştır. Sonuç olarak, binalarda yangına karşı direncin artırıması için Türkiye'de mimarlık ve iç mimarlık bölümlerinde yangına bağlı eğitimlerin yaygınlaştırılması elzemdir.
\end{abstract}

Anahtar Kelimeler: Yangın, yangın güvenliği, yangın eğitimi

\section{A View from Samsun to the Fire Safety in Architecture And Interior Design Education in Turkey}

\begin{abstract}
Fire is one of the most important dangers to be addressed due to both damaging to buildings and negative effects on people. The resistance of a building to fire is an educational problem as well as a technical issue. In this context, fire safety education of architects and interior designers becomes vital verily. Although it is not required to know fire safety at the expert level, the architects and interior designers are expected to know the relevant regulations and requirements and can use this information in the design. However, the fire-related training processes of architects and interior designers must be provided directly and effectively during vocational training. With this respect, basic education and information given directly related to the fire safety at the universities attached to Turkey are analyzed in this study with the survey conducted at Ondokuz Mayıs University, the Faculty of Architecture. Besides, the things to be done about the issue are evaluated extensively and suggestions are made for the decision-makers. Due to the lack of relevant resources, this study contains information that will shed light on the researches to be conducted in terms of the conclusions
\end{abstract}

\footnotetext{
${ }^{1}$ Dr. Öğretim Üyesi. Ondokuz Mayıs Üniversitesi, Mimarlık Fakültesi, Samsun, Türkiye

*ilgili yazar / Corresponding author: boduralper@yandex.com
} 
and recommendations it brings. It could be said that fire safety education in the departments of architecture and interior design in Turkey is still not spread enough and there are shortcomings in this regard. In conclusion, to increase the resistance against fire in buildings, it is vital to extend firerelated education at the departments of architecture and interior design in Turkey.

Keywords: Fire, fire safety, fire education

\section{GiRiş}

Ateşin varlığı, insanların tarih sahnesine çıkmaya başlamasından bu yana insan hayatında olan ve onu etkileyen bir durumu ifade etmektedir. Yerleşik hayata geçen insan, ateşi bu süreçten sonra günlük hayatının içine daha fazla almış olmakla birlikte ateşin insanoğluna yıkıcı etkisi oldukça fazla olmuştur.

Binalarda çeşitli nedenlerle ortaya çıkan yangınlar can ve mal güvenliği açısından büyük riskler oluşturmaktadır (Demirel ve diğ, 2017). Yangın, oksijen, yanıcı madde ve tutuşturucu kaynağın birleşmesi sonucu oluştuğundan (Şimşek, 2018), bu üç bileşenin birlikte olduğu her yerde ortaya çıkabilmektedir. Binalarda yangın korunumunun en öncelikli konuları can güvenliği, taşıyıcı sistemin/strüktürün korunumu ve yangının önlenmesidir (Beyhan, 2015).

Yangının diğer felaketlerden farkı, ateşin insan emrine tam olarak girmemesi, ancak öte yandan erişiminin dışında da olmaması, önleme ve söndürme tekniklerinin bilinmesi ve geliştirilmesidir (Esin, 2018). Yangın, geçmişten bu yana hem önceki yapılara verdiği hasar, hem de o yapılarda yaşayan insanlara verdiği olumsuz psikolojik etkisi sebebiyle üzerinde durulması gereken tehlikelerin en önemlilerinden biridir. Geçmişten bugüne önemli bir şehir olan İstanbul, Roma, Bizans ve Osmanlı dönemlerinde yangınlardan çok çile çekmiştir (Ürekli, 2010). İstanbul, yüzlerce yıllık tarihi boyunca geçirdiği yangınlar dolayısıyla tekrar tekrar inşa olunan nadir şehirlerden biridir (Yıldız, 2012). Yangınlar, İstanbul tarihinde depremlere göre şehre daha büyük zararlar vermiştir (Köse, 2019). Tarihten beri değeriyle en önemli yapılardan olan Ayasofya, İmparator Konstantios (337-361) tarafından 360 yılında yapılmış olup çıkan anlaşmazlıklar ve patriğin sürgüne gönderilmesi üzerine 404 yılında çıkan halk ayaklanması sonucunda yakılıp yıkılmıştır (Url-1).

İstanbul'da ekonomik sebeplerden dolayı uzun yıllar ahşap malzemenin kullanılması yapıların yangınlara tümüyle teslim olmasına sebep olmuştur (Kocaoğlu, 2016; Keyvanoğlu, 2017; Ürekli, 2010). Osmanlı Döneminde İstanbul'da oluşan yıkıcı yangınlar; yedi gün süren 1569 yılı yangını (Esin, 2018), 1633 yılı Cibali yangını (Ürekli, 2010), on binlerce evin yandığı 1660 yılı Galata yangını (Yıldız, 2014), 1500 ev, 5000 dükkan ve işyerinin kül olduğu 1688 yılı Balıkpazarı yangını ve iki gün süren 1718 yılı Cibali yangını (Ürekli, 2010), 1756 yılında şehrin üçte birini yakan Cibali yangını (Köse, 2019), İstanbul'un karşılaştığı en büyük âfetlerden birisi olan 1782 yılı yangını, Tanzimat dönemi yangınları, 1911 yılı Uzunçarşı yangını (Ürekli, 2010) karşılaşılan en yıkıcı afetlerdendir.

Tüm bu yangınlarla beraber birtakım önlemlerde alınmıştır. XVI. yüzyılın ortalarında, özellikle evlerin nasıl yapılması ve yapılmaması gerektiği yolunda önemli kararların alındığı bilinmektedir (Yıldız, 2012). 1660 yılı yangını sonrasında devlet tarafından, şehrin nüfus ve mimari yapısına farklııı getiren birtakım kararlar alınmış ve uygulanmıştır (Yıldız, 2014). Alınan tedbirlerin başında ocak ve bacaların süpürülüp temizlenmesi, yeni yapılacak binaların kârgir ve kirpi saçaklı olarak yapılması, surlara yakın ev yapılmaması gibi maddeler gelmektedir (Yıldız, 2012). Tanzimatla birlikte yangınları önlemek için yeni önlemler alınmıştır. Kârgîr binaların yapılması ve yeni yapıların arasındaki sokakların geniş bırakılması zorunlu hale getirilmiştir (Korkmaz). XIX. Yüzyılda yangına karşı önlem olarak çıkmaz sokakların ortadan kaldırılması ve caddelerin düzeltilmesi amaç edinilmiş, ayrıca ahşap 
evlerin yapımı da yasaklanmıştır (Korkmaz). Sonuç itibariyle, İstanbul örneğinde görüldüğü üzere, Osmanlı döneminde yangınlar oldukça ciddi yıkımlara yol açmış, devlet bununla ilgili tedbirler almaya çalışmıştır.

19. Yüzyılda ortaya çıkan betonarme malzeme, binaların yangınlara karşı direnmesinde önemli bir mesafe kat etmeye vesile olmuştur (Url-2). Yine de, dünya nüfusunun artması ile birlikte yangın artmaya devam etmiştir. Yangın, eski tarihlerde savaşlar ve başka kavimlerin yerleşik kavimlere saldırısı sonucu oluşurken, günümüze yaklaştıkça insan kaynaklı olarak meydana gelmektedir. Örneğin, araştırma kapsamında ele alınan Samsun kenti, nüfusla beraber yangınların arttığı ve yangınlara karşı mücadele edilen kentlerden biridir. Kent, tarihten bu yana farklı toplumların hükümdarlığında yönetilmiştir. M.Ö. 1200'lü yıllarda Frig saldırıları ile yakılıp yıkılan kent, Osmanlı ve Cenevizlilerin mücadelelerinde de yakılmıştır (Özcan, 2014; Url-3).

Nüfusun 18.000 civarında olduğu 1869 Büyük Samsun yangınında (Erler, 2000), 415 adet ev yanmıştır (Url-4). 1869 yangını, petrol ürünleri satan bir dükkândaki varillerin ateş alarak etrafa yayılması şeklinde oluşmuştur (Altaylı, 1967). Günümüze gelindiğinde ise kentte yangınlar artmıştır. Samsun İtfaiyesi verilerine göre 2018 yılında toplam 5064 olaydan 1800'ü yangındır. 1800 adet yangından 148 adedi işyeri yangını, 503 adedi ise konut yangınıdır. Yangınların çoğu nüfusun daha fazla olduğu Atakum, İlkadım ve Bafra gibi ilçelerde meydana gelmektedir (Samsun İtfaiyesi, 2018). Ayrıca belirtilmelidir ki, otlak alanlar gibi bina yerleşim alanlarına yakın yerlerde oluşan yangınlarda duman etkisiyle o yerleşmede yaşayan insanlara ve mallara zarar verebilmektedir. Özetle, Samsun kenti özelinde görüldüğü gibi, yangın geçmişte savaş ve iktidar mücadeleleri sebebiyle meydana gelirken, günümüzde çoğunluğu insan kaynaklı olup tedbirsizlik sonucu oluşmaktadır.

\section{YANGIN GÜVENLIGĞi DERSLERI VE ANKET UYGULAMALARI}

Yangın da dâhil olmak üzere, binalar tüm afetlere karşı sağlam olmak zorundadır. Ancak, mimari açıdan bazen estetik kaygılar daha ön plana çıkmakta, sağlamlık ve dayanıklılık bir anlamda göz ardı edilmektedir. Oysa bina hem sağlam olmalı, hem de estetik kaygıları göz önünde bulunduran bir eser olmalıdır. Mimari bir eser, sağlamlık açısından değerlendirildiğinde, öncelikle yangın gibi dış etkilere karşı sağlam olmalıdır. Yangına karşı sağlamlık ve dirençlilik, teknik bir konu olduğu kadar eğitiminde konusudur. Bu açıdan bakıldığında, mimarlık ve iç mimarlık eğitiminde yangın bilgisine ihtiyaç bulunmaktadır. Böylece, mimari ürünün yangına karşı sağlamlığı, mimarların ve ayrıca iç mimarların yangın güvenliği ile ilgili eğitim seviyelerinin yüksek tutulması ile artacaktır.

Türkiye'de yapılar inşa edilmeden proje aşamasında, resmi kurumlar tarafından mutlaka yangına karşı alınan tedbirler yönünden incelenmektedir. Bu sebeple, hem yapıyı tasarlayan hem de yapıyı yangın güvenliği aşısından kontrol eden ve denetleyen mimar ve iç mimarların yangın güvenliği kuralları ve standartları ile ilgili yeterince bilgi sahibi olması beklenmektedir. Bu açıdan, yangınla ilgili bilgi ve eğitim süreçlerinin meslek öğretimi sırasında doğrudan ve etkin bir biçimde verilmesi oldukça önem arz etmektedir.

Yukarıdaki bilgiler bağlamında, binalarda yangın güvenliğinin, mimarlar ve iç mimarlar tarafından eğitim aşamasında hangi seviyede bilindiğini ölçmek amaçlanmıştır. Bu sebeple, 2018-2019 Güz Döneminde, Ondokuz Mayıs Üniversitesi Mimarlık Fakültesi'nde Mimarlık ve İç Mimarlık Bölümlerine ortak olarak 7. Yarıyılda verilen "Binalarda Yangın Güvenliği” dersi öncesinde, dersi alan öğrencilere yangınla ilgili bazı temel soruları içeren anket uygulanmıştır. 


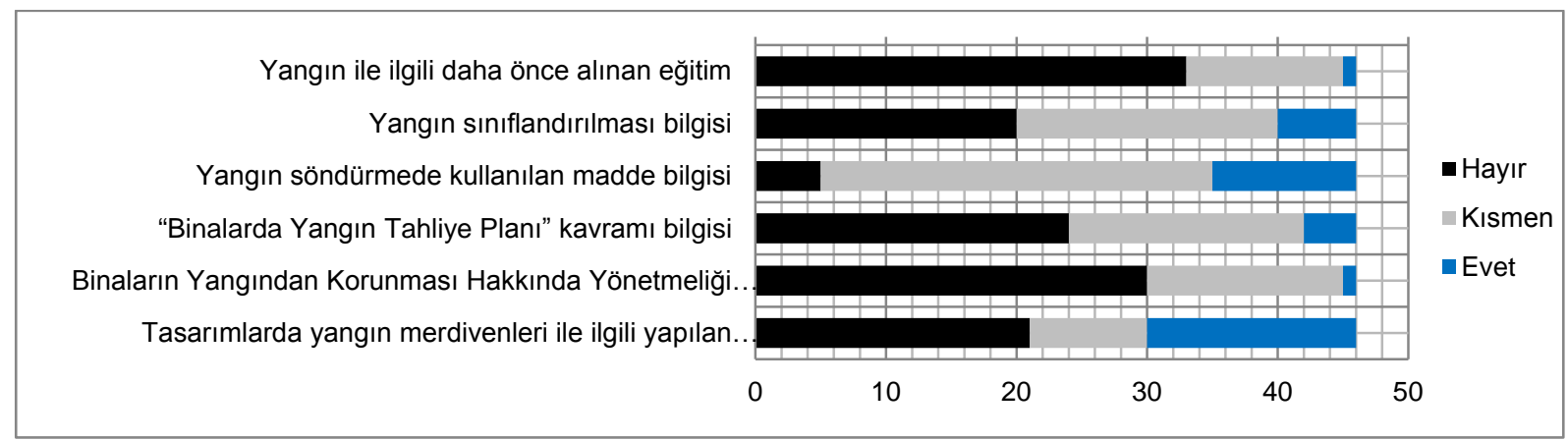

Şekil 1. Ders öncesi yapılan anket sonuçları.

Şekil 1'de gösterildiği şekilde, dersi alan toplam 74 öğrenciden 46 öğrencinin katıldığı ankette, daha önce yangın ile ilgili eğitim alan öğrenci sayısı 1 (\%2,2), kısmen alan 12 $(\% 26,1)$, hiç almayan $33(\% 71,7)$ öğrencidir. Yangınların sınıflandırılması ile ilgili bilgisi olan öğrenci sayısı $6(\% 13,0)$, kısmen bilen 20 (\%43,5), hiç bilmeyen $20(\% 43,5)$ öğrencidir. Yangınlarının söndürülmesinde hangi maddelerin kullanıldığını 11 öğrenci $(\% 23,9)$ bilmekte, $5(\% 10,9)$ öğrenci hiç bilmemekte, $30(\% 65,2)$ öğrenci ise kısmen bilmektedir. Binalarda yangın tahliye planı ile ilgili bilgisi olan öğrenci sayısı 4 (\%8,7), kısmen bilen $18(\% 39,1)$, hiç bilmeyen 24 (\%52,2)'tür. Binaların Yangından Korunması Hakkında Yönetmelik ile ilgili bilgisi olan öğrenci sayısı 1 (\%2,2), kısmen bilen 15 (\%32,6), hiç bilmeyen $30(\% 65,2)$ öğrencidir. Tasarımlarında yangın merdiveni ile ilgili çalışma yapan $16(\% 34,8)$, kısmen yapan 9 $(\% 19,6)$, hiç yapmayan 21 (\%45,6) öğrencidir. Bu verilere göre mimarlık ve iç mimarlık öğrencilerinin binalarda yangın güvenliği ile ilgili neredeyse her açıdan yok denecek kadar bilgisi olduğu görülmektedir.

$\mathrm{Bu}$ sebepten dolayı, Türkiye'de bulunan diğer üniversitelerin durumunun açıklanması zaruridir. YÖK verilerine göre, 2019 yılı itibariyle 129 devlet, 73 vakıf, 5 Vakıf MYO olmak üzere Türkiye'de toplam 207 üniversite bulunmaktadır. Üniversitelerde okuyan öğrenci sayısı, üniversite sayısı artışına paralel olarak artmıştır. Bununla beraber, ülkeler arası insan hareketliliğinin tetiklemesi ile birlikte, başka ülkelerden üniversitelerimize gelen öğrenci sayısında da artış bulunmaktadır. 2013-2014 eğitim-öğretim yılında öğrenci sayısı 5.619.079 iken, 2018-2019 eğitim-öğretim yılında 7.740.502 olmuştur (Url-5).

2017-2018 Eğitim-Öğretim döneminde üniversiteye alınan öğrenci kontenjanlarında da artışlar olmuştur. Bunların başında \%432,4 ile büyüyen iç mimarlık ile iç mimarlık ve çevre tasarımı bölümü gelmektedir. Diğer yandan, 2005 yılında öğrencilerin tercih ettikleri bölümlerden mimarlık bölümü, 2005 yılında 12. sırada tercih edilirken 2015 yılında 5. sırada tercih edilen bölüm olmuştur (TMMOB, 2017).

Tüm bunlarla birlikte, mimarlık ve iç mimarlık bölümleri, farklı fakülteler altında eğitim ve öğretim faaliyetlerine devam etmektedir. Alınan öğrencilerin puan türlerinde de farklııklar bulunmaktadır. İç mimarlık ve mimarlık bölümleri MF-4 puan türünden öğrenci alırken, iç mimarlık ve çevre tasarımı bölümü TM-1 türünden yeterli puan alan öğrencileri kabul etmektedir. International Standard Classification of Education (ISCED) verilerine göre iç mimarlık tek bir isim altında birleşmektedir. Bu çalışmada ise, Türkiye'ye bağlı üniversitelerdeki mevcut bölüm ve programlar irdelenmektedir. Mevcut koşullarla ilgili analizlerin ve ileriye yönelik önerilerin sağlıklı yapılabilmesi amacıyla, iç mimarlık ile iç mimarlık ve çevre tasarımı bölümleri ile ilgili inceleme ve değerlendirmeler ayrı şekillerde ele alınmaktadır. Buna göre, mimarlık ve iç mimarlık eğitimleri ile ilgili hem öğrenci alımlarında, hem de eğitim süresince yangın güvenliği açısından ortak bir eğitim politikasına varılamadığı, farklı şekillerde ve içeriklerde eğitim ve öğretimin devam ettiği anlaşılmaktadır. 
Türkiye'de mimar ve iç mimarların mevcut sayısı incelendiğinde, konunun önemi daha iyi anlaşılabilecektir. 1 Ocak 2017 itibariyle 22.223 kadın ve 28.767 erkek olmak üzere 50.990 mimar, 2.176 kadın ve 2.153 erkek olmak üzere 4.329 iç mimar TMMOB'ne kayıtlı görünmektedir. Bu bölümlerin 2017-2018 öğrenci kontenjanları ise mimarlık için 6.956, iç mimarlık için ise 3.853'tür (TMMOB, 2017). 2018-2019 eğitim ve öğretim yılına gelindiğinde ise, mimarlık bölümünde okuyan öğrenci sayısı 40.215 , iç mimarlık bölümünde 9.083 , iç mimarlık ve çevre tasarımı bölümünde ise 9.562'ye ulaşmıştır (Url-5). Mimarlık ve iç mimarlığın öneminin tüm bu gelişmelerle daha da arttığı görülmektedir.

Türkiye'deki üniversitelerde bulunan mimarlık ve iç mimarlık (iç mimarlık ve çevre tasarımı dahil) bölümlerinin bazılarında yangın güvenliği ile ilgili doğrudan dersler verilmektedir.

YÖK Atlas verilerine göre; 171 adet üniversitede bu üç bölüme ait (8 adet KKTC ve 2 adet yurtdışı dâhil), İngilizce ücretli, İngilizce burslu, İngilizce \%50 indirimli, \%75 indirimli, \%50 indirimli, burslu, ücretsiz ve ikinci öğretim olmak üzere, 440 adet program bulunmaktadır. Bu programlarda, yangın güvenliği ile ilgili 28 tanesi mimarlık, 9 tanesi iç mimarlık ve 11 tanesi iç mimarlık ve çevre tasarımı olmak üzere (Tablo 1) 48 adet doğrudan ders bulunmaktadır (Url6). 20 programın verilerine ulaşılamamış olup 372 adet programda yangın güvenliği ile ilgili doğrudan ders bulunmamaktadır.

Tablo 1. Bölümler ve programlara ait sayısal veriler (YÖK Atlas verilerinden derlenmiştir).

\begin{tabular}{|l|c|c|c|c|c|}
\hline \multicolumn{1}{|c|}{ Bölüm } & $\begin{array}{c}\text { Üniversite } \\
\text { Sayısı }\end{array}$ & $\begin{array}{c}\text { Program } \\
\text { Sayısı }\end{array}$ & $\begin{array}{c}\text { Program } \\
\text { Bazında } \\
\text { Yangın Dersi } \\
\text { Var }\end{array}$ & $\begin{array}{c}\text { Program } \\
\text { Bazında } \\
\text { Yangın Dersi } \\
\text { Yok }\end{array}$ & $\begin{array}{c}\text { Program } \\
\text { Bazında Bilgiye } \\
\text { Erişilemedi }\end{array}$ \\
\hline Mimarlık & 106 & 247 & 28 & 206 & 13 \\
\hline İç Mimarlık & 32 & 88 & 9 & 75 & 4 \\
\hline İç Mimarlık ve Çevre Tasarımı & 33 & 105 & 11 & 91 & 3 \\
\hline Genel Toplam & 171 & 440 & 48 & 372 & 20 \\
\hline
\end{tabular}

Mimarlık bölümleri incelendiğinde, 51 devlet, 45 vakıf, 8 KKTC ve YÖK'e bağlı 2 yurtdışı üniversitesi olmak üzere toplam 106 üniversitede 247 farklı program bulunmaktadır. Bu programlardan yangın güvenliği dersi verilip verilmediği ile ilgili veriler incelendiğinde, 13 adedinde bilgiye ulaşılamamış, 206 adedinde dersin olmadığı tespit edilmiş olup 12'si devlet, 16 adedi ise vakıf üniversiteleri olmak üzere toplam sadece 28 adedinde ders olduğu gözlenmiştir. Derslerin verildiği programlar detaylı incelendiğinde, yapılarda yangın güvenliği, yangın korunumu, yapılarda yangın ve afet güvenliği, yapılarda yangın önlemleri vb. gibi isimlerle verildiği görülmektedir. Ayrıca, derslerin verildiği dönemlerde de değişiklikler bulunmakta, dersler 8. Yarıyıldan 4. Yarıyıla kadar farklı dönemlerde verilmektedir. 
Tablo 2. Mimarlık bölüm ve programlarına ait sayısal veriler (YÖK Atlas verilerinden derlenmiştir).

\begin{tabular}{|l|l|c|c|c|c|c|}
\hline \multirow{4}{*}{ Bölüm } & \multicolumn{1}{|c|}{$\begin{array}{c}\text { Üniversite } \\
\text { Tipi }\end{array}$} & $\begin{array}{c}\text { Üniversite } \\
\text { Sayısı }\end{array}$ & $\begin{array}{c}\text { Program } \\
\text { Sayısı }\end{array}$ & $\begin{array}{c}\text { Program } \\
\text { Bazında } \\
\text { Yangın Dersi } \\
\text { Var }\end{array}$ & $\begin{array}{c}\text { Program } \\
\text { Bazında } \\
\text { Yangın } \\
\text { Dersi } \\
\text { Yok }\end{array}$ & $\begin{array}{c}\text { Program } \\
\text { Bazında } \\
\text { Bilgiye } \\
\text { Erişilemedi }\end{array}$ \\
\hline \multirow{3}{*}{ Mimarlık } & Devlet & 51 & 53 & 12 & 37 & 4 \\
\cline { 2 - 8 } & Vakıf & 45 & 169 & 16 & 149 & 4 \\
\cline { 2 - 8 } & KKTC & 8 & 23 & 0 & 19 & 4 \\
\cline { 2 - 8 } & Yurtdışı & 2 & 2 & 0 & 1 & 1 \\
\hline \multirow{2}{*}{ Genel Toplam } & 106 & 247 & 28 & 206 & 13 \\
\hline
\end{tabular}

İç Mimarlık bölümleri incelendiğinde, 9 devlet, 17 vakıf ve 6 KKTC üniversitesi olmak üzere toplam 32 üniversitede 88 farklı program bulunmaktadır. Bu programlardan yangın güvenliği ile ilgili doğrudan ders verilip verilmediği ile ilgili verilere bakıldığında, 4 adedinde bilgiye ulaşılamamış, 75 adedinde dersin olmadığı tespit edilmiş olup 1'i devlet, 3 adedi vakıf ve 5 adedi KKTC üniversiteleri olmak üzere toplam sadece 9 adedinde ders olduğu gözlenmiştir. Derslerin verildiği programlar detaylı incelendiğinde, mimarlık programlarında olduğu gibi, yangın güvenliği ve yangın korunumu gibi isimlerle verildiği anlaşılmaktadır. Ayrıca, derslerin verildiği dönemlerde de değişiklikler bulunmaktadır. Yangın güvenliği ile ilgili dersler, 8. Yarıyıldan 3. Yarıyıla kadar farklı dönemlerde verilmektedir.

Tablo 3. İç Mimarlık bölüm ve programlarına ait sayısal veriler (YÖK Atlas verilerinden derlenmiştir).

\begin{tabular}{|l|l|c|c|c|c|c|}
\hline \multirow{4}{*}{ Bölüm } & $\begin{array}{c}\text { Üniversite } \\
\text { Tipi }\end{array}$ & $\begin{array}{c}\text { Üniversite } \\
\text { Sayısı }\end{array}$ & $\begin{array}{c}\text { Program } \\
\text { Sayısı }\end{array}$ & $\begin{array}{c}\text { Program } \\
\text { Bazında } \\
\text { Yangın Dersi } \\
\text { Var }\end{array}$ & $\begin{array}{c}\text { Program } \\
\text { Bazında } \\
\text { Yangın } \\
\text { Dersi } \\
\text { Yok }\end{array}$ & $\begin{array}{c}\text { Program } \\
\text { Bazında } \\
\text { Bilgiye } \\
\text { Erişilemedi }\end{array}$ \\
\hline \multirow{3}{*}{ İç Mimarlık } & Devlet & 9 & 10 & 1 & 8 & 1 \\
\cline { 2 - 7 } & Vakıf & 17 & 57 & 3 & 51 & 3 \\
\cline { 2 - 7 } & KKTC & 6 & 21 & 5 & 16 & 0 \\
\cline { 2 - 7 } & Yurtdışı & 0 & 0 & 0 & 0 & 0 \\
\hline
\end{tabular}

İç Mimarlık ve Çevre Tasarımı bölümleri incelendiğinde, 5 devlet ve 28 vakıf üniversitesi olmak üzere toplam 33 üniversitede 105 farklı program bulunmaktadır. Bu programlardan yangın güvenliği ile ilgili doğrudan ders verilip verilmediği incelendiğinde, 3 adedinde bilgiye ulaşılamamış, 91 adedinde dersin olmadığı tespit edilmiş olup 1'i devlet, 10 adedi vakıf üniversiteleri olmak üzere toplam sadece 11 adedinde ders olduğu gözlenmiştir. Derslerin verildiği programlar detaylı incelendiğinde, mimarlık ve iç mimarlık bölümlerinde olduğu gibi, akustik ve yangın güvenliği, bina güvenliği, binalarda servis sistemleri ve yangın denetimi gibi isimlerle verildiği anlaşılmaktadır. Ayrıca, derslerin verildiği dönemlerde de değişiklikler bulunmaktadır. Yangın güvenliği ile ilgili dersler, 6. Yarıyıl, 7. Yarıyıl ve 8. Yarıyıla kadar farklı dönemlerde verilmektedir. 
Tablo 4. İç Mimarlık ve Çevre Tasarımı bölüm ve programlarına ait sayısal veriler (YÖK Atlas verilerinden derlenmiştir).

\begin{tabular}{|l|l|c|c|c|c|c|}
\hline \multirow{2}{*}{ Bölüm } & $\begin{array}{c}\text { Üniversite } \\
\text { Tipi }\end{array}$ & $\begin{array}{c}\text { Üniversite } \\
\text { Sayısı }\end{array}$ & $\begin{array}{c}\text { Program } \\
\text { Sayısı }\end{array}$ & $\begin{array}{c}\text { Program } \\
\text { Bazında } \\
\text { Yangın Dersi } \\
\text { Var }\end{array}$ & $\begin{array}{c}\text { Program } \\
\text { Bazında } \\
\text { Yangın } \\
\text { Dersi } \\
\text { Yok }\end{array}$ & $\begin{array}{c}\text { Program } \\
\text { Bazında } \\
\text { Bilgiye } \\
\text { Erişilemedi }\end{array}$ \\
\hline \multirow{4}{*}{$\begin{array}{l}\text { İç Mimarlık } \\
\text { ve } \\
\text { Çevre Tasarımı }\end{array}$} & Devlet & 5 & 7 & 1 & 5 & 1 \\
\cline { 2 - 8 } & Vakıf & 28 & 98 & 10 & 86 & 2 \\
\cline { 2 - 8 } & KKTC & 0 & 0 & 0 & 0 & 0 \\
\cline { 2 - 8 } & Yurtdışı & 0 & 0 & 0 & 0 & 0 \\
\hline
\end{tabular}

Sonuç itibariyle, 3 farklı bölümde verilen yangın güvenliği derslerinin, Türkiye'ye bağlı üniversitelerin tümünde yeterince ele alınmadığı, verilen derslerin ise farklı isimler altında ve farklı dönemlerde verildiği anlaşılmaktadır. Bu konuda, üniversiteler arasında ortak bir tutuma varılamadığı açıkça görülmektedir.

Binalarda Yangın Güvenliği dersinin son haftasında, yangın güvenliği ile ilgili farkındalığın artıp artmadığı ile ilgili, dersle ilgili temel sorular öğrencilere tekrar sorularak konu ile ilgili farkındalığın hangi aşamada olduğu değerlendirilmeye çalışılmıştır. Ders öncesinde 46 öğrencinin katıldığı ankete, dersin sonunda 53 öğrenci katımıştır.

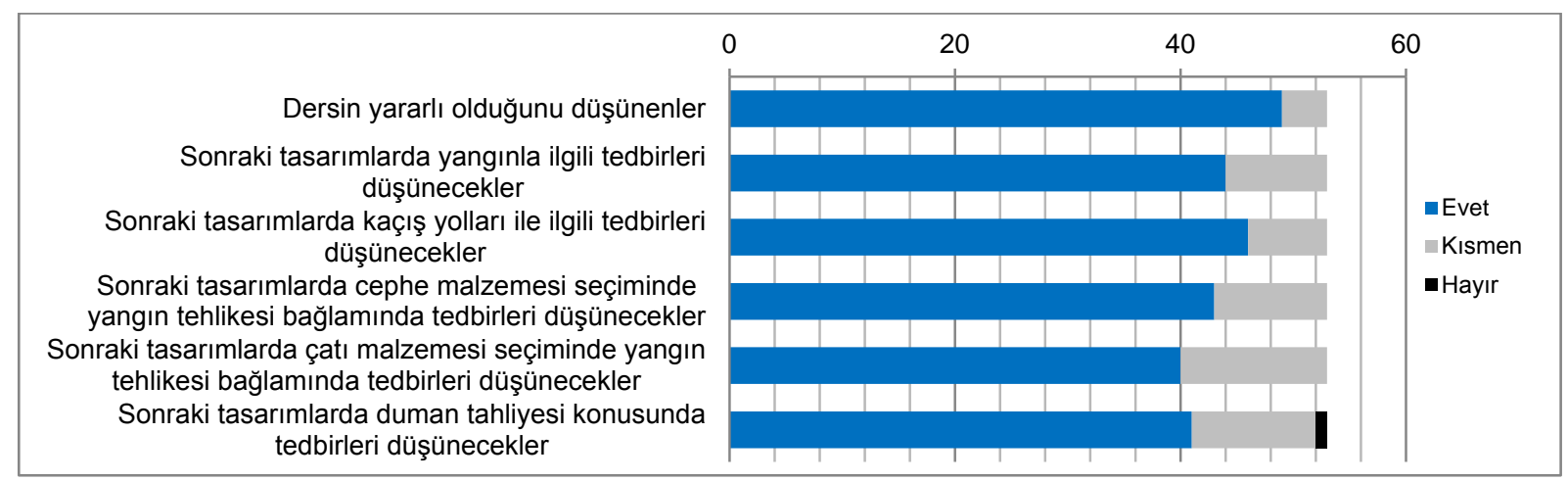

Şekil 2. Ders sonrası yapılan anket sonuçları.

Şekil 2'de görüldüğü şekilde, dersin yararlı olduğunu düşünen öğrenci sayısı $49(\% 92,4)$, kısmen yararlı olduğunu düşünen $4(\% 7,6)$ öğrencidir. Yararlı olmadığını düşünen öğrenci bulunmamaktadır. Bundan sonraki tasarımlarında yangınla ilgili tedbirleri düşünecek öğrenci sayısı $44(\% 83,0)$, kısmen $9(\% 17,0)$ adettir. Yangınlarla ilgili tedbir almayacak öğrenci bulunmamaktadır. Bundan sonraki tasarımlarında yangından kaçış yolları ile ilgili tedbirleri düşünecek öğrenci sayısı $46(\% 86,8)$, kısmen $7(\% 13,2)$ adettir. Tedbir almayacak öğrenci bulunmamaktadır. Bundan sonraki tasarımlarında cephe malzemesi seçiminde yangın tehlikesi bağlamında tedbirleri düşünecek öğrenci sayısı 43 (\%81,1), kısmen $10(\% 18,9)$ adettir. Tedbir almayacak öğrenci bulunmamaktadır. Bundan sonraki tasarımlarında çatı malzemesi seçiminde yangın tehlikesi bağlamında tedbirleri düşünecek öğrenci sayısı 40 $(\% 75,5)$, kısmen $13(\% 24,5)$ adettir. Tedbir almayacak öğrenci bulunmamaktadır. Bundan sonraki tasarımlarında duman tahliyesi konusunda tedbirleri düşünecek öğrenci sayısı 41 $(\% 77,4)$, kısmen $12(\% 22,6)$ adettir. Tedbir almayacak öğrenci bulunmamaktadır. Buna göre, mimarlık ve iç mimarlık öğrencilerinin binalarda yangın güvenliği dersi almaları durumunda, konu ile ilgili yeterli seviyede farkındalık edindiği görülmektedir. Bununla birlikte, sonraki aşamalarda yapacakları tasarımlarda ve çalışmalarda, yangınla ilgili önleyici tedbirleri düşünecekleri ortaya çıkmaktadır. 


\section{DEĞERLENDIRME VE SONUÇ}

Özgürce tasarlanmış binalarda özgürce gelişen yangınlar ağır can ve mal kayıplarına yol açabilirler. Yangınlarda ölüm ve yaralanmalar, binanın yangın güvenliğine uygun olarak tasarlanmaması sebebiyle oluşmaktadır. Bu sebeple, binaları tasarlayan mimar ve içmimarlar, yangın güvenliği ile ilgili bilgi sahibi olmalı ve bunları uygulamalıdırlar. Mimar ve iç mimarların yangınla ilgili bilgileri, eğitim aşamasından meslek yaşamına devam eden süreçte katlanarak artmalıdır.

Türkiye'deki üniversitelerde, bu açıdan, yangın güvenliği ile ilgili yeterli derecede eğitim verildiğini söylemek mümkün görünmemektedir. Ayrıca, verilen dersler incelendiğinde, derslerin isimlerinde ve verildikleri dönemlerde ortak bir tutuma varılamamıştır. $\mathrm{Bu}$ bağlamda, yangın güvenliği ile ilgili derslerin, en fazla 2 isimle (binalarda yangın korunumu, binalarda yangın güvenliği gibi) verilmesi, mümkünse mimarlık ve iç mimarlık programlarının aynı fakülteye bağlanarak dersin ortak verilmesi konunun ciddiyeti ve ortak bir bakış açısı oluşturulması açısından önem arz etmektedir. Bununla birlikte, yangın güvenliği gibi teknik bir konunun verileceği döneminde, dersi veren ya da verecek olan üniversiteler tarafından daha dikkatli seçilmesi elzemdir. Bu açıdan, yangın güvenliği dersinin, öğrencilerin bazı teknik bilgileri aldıktan sonra verilmesi gerekmektedir. 6. veya 7. Yarıyıllar bunun için en uygun dönemler olarak gözükmektedir. Üniversitelerin mevcut müfredatlarını yenileyerek yangın güvenliği dersinin verildiği dönemin güncellenmesi gerekmektedir. Sonuç olarak, binalarda oluşacak yangınlarla bilinçli bir şekilde topyekün mücadele etmenin en önemli yollarından birisi, binaları tasarlayan mimar ve iç mimarların doğru zamanda, doğru bilgiler ile donatılarak güvenli tasarımlar oluşturabilmesinden geçmektedir.

\section{NOT}

Bu çalışma, "IDRC 2019 from Risk to Resilience" kongresinde sözlü olarak sunulan "Türkiye'de Mimarlık ve İç Mimarlık Öğretiminde Yangın Güvenliğinin Yeri” isimli bildiriye dayanmaktadır. 


\section{KAYNAKLAR}

Altaylı, A. (1967). Samsun Tarihi. Samsun: Yüceer Matbaası.

Beyhan, F. (2015). Mimari Bir Bağlam Olarak Binalarda Çeliğin Yangından Korunumu. TUCSA Web Yayınlar, http://www.tucsa.org/tr/yayinlar.aspx?yayin=3.

Demirel, F., Tavman, G., Yaman, M. (2017). Gazi Üniversitesi Yeni Mimarlık Fakülte Binasının "Binaların Yangından Korunması Hakkında Yönetmelik" Bağlamında Incelenmesi. TÜYAK Uluslarası Yangın ve Güvenlik Sempozyumu ve Sergisi, İstanbul, Türkiye: Kasım 910.

Erler, M. (2000). 1870 Yılında Doğu Karadeniz'de Çıkan Yangın ve Etkileri. Tarih Araştırmaları Dergisi, 20 (31), 209-218.

Esin, T. (2018). Felaketleri Yönetmek: Osmanlı Kent Yangınlarının Kullanımları (16-18. Yüzyıl). Kebikeç İnsan Bilimleri İçin Kaynak Araştırmaları Dergisi, 22 (45), 297-327.

Keyvanoğlu, M. C. (2017). 1870 Büyük Beyoğlu Yangını. OTAM(Ankara Üniversitesi Osmanlı Tarihi Araştırma ve Uygulama Merkezi Dergisi), 41, 169-190.

Kocaoğlu, B. (2016). Osmanlı'da Cizye Vergisi ve Itfaiye Çalışmaları. Iğdır Üniversitesi Sosyal Bilimler Dergisi, 10, 155-167.

Korkmaz, Ş. (2010). Çanakkale'de Yangınlar (1836-1866). Tarih Araştırmaları Dergisi, 29 (48), 51-67. Retrieved from https://dergipark.org.tr/tr/pub/tariharastirmalari/issue/47785/603660

Köse, F . (2019). 1756 İstanbul Yangını. Mevzu - Sosyal Bilimler Dergisi , (2) , 191-213 . Retrieved from https://dergipark.org.tr/tr/pub/mevzu/issue/49072/608933

Özcan, S. (2014). Samsun Hükümet Konağı Yangını (1883). Ondokuz Mayıs Üniversitesi Eğitim Fakültesi Dergisi, 12 (1), 153-159. Retrieved from https://dergipark.org.tr/tr/pub/omuefd/issue/20260/215189

Samsun İtfaiyesi, (2018). Samsun Büyükşehir Belediyesi Itfaiye Dairesi Başkanlığı Faaliyet Raporu 2018. Samsun.

Şimşek, Z. (2018). Yangın Güvenliğinin Mimari Proje Derslerinde Sorgulanmasında Yangın Korunumu İçerikli Derslerin Etkisinin Değerlendirilmesi. Uluslararası Sosyal Araştırmalar Dergisi, 11 (58), 39-406.

TMMOB, (2017). TMMOB Eğitim Sempozyumu, 22-23 Aralık 2017, Ankara.

(Url-1). https://ayasofyamuzesi.gov.tr/tr/content/tarih\%C3\%A7e. [Erişim 20 Ağustos 2019].

(Url-2). http://mmf2.ogu.edu.tr/atopcu/index_dosyalar/Tarih/BeTarihi.pdf. [Erişim 18 Ağustos 2019].

(Url-3). https://samsun.ktb.gov.tr/TR-59809/tarih.html. [Erişim 17 Temmuz 2019].

(Url-4). http://www.samsun.gov.tr/gecmisten-gunumuze-samsun. [Erişim 22 Temmuz 2019].

(Url-5). https://istatistik.yok.gov.tr/. [Erişim 12 Ağustos 2019].

(Url-6). https://yokatlas.yok.gov.tr/. [Erişim 21 Ağustos 2019].

Ürekli, F. (2010). Osmanlı Döneminde İstanbul'da Meydana Gelen Âfetlere Illişkin Literatür.

Türkiye Araştırmaları Literatür Dergisi, (16), 101-130. Retrieved from https://dergipark.org.tr/tr/pub/talid/issue/43423/529327

Yıldız, K. (2012). 1660 İstanbul Yangınının Sosyo-Ekonomik Tahlili. (Yayınlanmamış Doktora Tezi). Marmara Üniversitesi Türkiyat Araştirmalari Enstitüsü.

Yıldız, K. (2014). Doğruluğu Tartışmalı Bir Tartışma: 1660 Yangını İstanbul'un İslâmlaşmasına Etki Etti mi?. (Ed. Emecen, F. M. ve Gürkan E. S.) Osmanlı İstanbulu Uluslararası Sempozyum-I (29 Mayıs - 1 Haziran 2013), İstanbul: İstanbul 29 Mayıs Üniversitesi, 2014, s. 197-242. 